\title{
Air Pollution: a New Risk Factor for Developing Stroke
}

\author{
Vida Demarin ${ }^{1}$ (D), Sandra Morović ${ }^{2}$, Filip Đerke ${ }^{3}$ \\ ${ }^{1}$ International Institute for Brain Health, Zagreb, Croatia \\ ${ }^{2}$ Aviva Medical Center, Zagreb, Croatia \\ ${ }^{3}$ Department of Neurology, Clinical Hospital Dubrava, Zagreb, Croatia
}

ABSTRACT:

Many years scientist try to explore the connection between air pollution and its influence on human health and after numerous conducted researches they came up with the clear evidence that air pollution has a significant impact on overall health and especially on stroke. In the Global Burden of Disease Study, it has emerged as a significant contributor to the global stroke burden, especially in low- and middle-income countries.

Furthermore, these and some other researches have suggested a closer link between air pollution and ischemic stroke, due to huge diversity of the results of numerous other studies, for drawing definitive conclusions, further research is still needed.

Due to the complexity of stroke with its types and subtypes, the results of their reaction to air pollution differ. Some studies have shown the link between cardioembolic stroke and AP, others with SAH but not with intracerebral haemorrhage. There was a suggestion that nitrogen dioxide exposure might be associated with stroke caused by small vessel disease, while other studies are not reporting any association of AP and the risk of ischemic stroke. In some studies, AP was more affecting young adults and in some, it was more pronounced in women. Some studies reported a more clear link between AP and recent stroke in patients with other risk factors like diabetes and previous stroke.

Studies have varied by the concentration and types of pollutants studied, which vary geographically, as well as by duration to AP exposure being short- or long-term, and in some studies being present only during warm

OPEN ACCESS

Correspondence: Vida Demarin MD PhD vida.demarin@gmail.com orcid.org/0000-0003-4942-259x

This article was submitted to RAD CASA - Medical Sciences as the review article

Conflict of Interest Statement: The authors declare that the research was conducted in the absence of any commercial or financial relationships that could be construed as a potential conflict of interest.

Received: 11 October 2019 Accepted: 29 October 2019 Published: 17 December 2019

Citation:

Demarin V, Morovic S and Derke F. Air Pollution: a New Risk Factor for Developing Stroke. RAD CASA - Medical Sciences. 540=48-49 (2019):51-57. https:// dx.doi.org/10.21857/mzvkptz3n9

Copyright (C) 2019 Demarin, Morovic and Derke. This is an open-access article distributed under the terms of the Creative Commons Attribution License (CC BY). The use, distribution or reproduction in other forums is permitted, provided the original author(s) and the copyright owners(s) are credited and that owners( $s$ ) are credited and that the original publication in this journal is cited, in accordance whit accepted adacemic
practice. No use, distribution or reproduction is permitted which does not comply with these terms. seasons.

Regulations have improved air quality in many countries in Europe and the United States, resulting in greater life expectancy, which highlights the continued importance of further efforts in that direction.

KEYWORDS: Air pollution; Stroke risk factors; Pollutant concentration; Exposure duration.

\section{SAŽETAK:}

\section{ZAGAĐENJE ZRAKA: NOVOOTKRIVENI FAKTOR RIZIKA U RAZVOJU MOŽDANOG UDARA}

Već nekoliko godina znanstvenici pokušavaju istražiti povezanost zagađenja zraka i njegovog utjecaja na zdravlje ljudi, a nakon brojnih provedenih istraživanja došli su do jasnih dokaza da zagađenje zraka ima značajan utjecaj na cjelokupno zdravlje, s posebnim naglaskom na ravoj moždanog udara. U "Global Bourden of Disease” (szo)pokazalo se da zagađeni zrak značajno doprinosi globalnom opterećenju od moždanog udara, posebno u zemljama s niskim i srednjim dohotkom.

Nadalje, ova i neka druga istraživanja sugeriraju blisku povezanost zagađenja zraka i ishemijskim moždanim udarom, dok zbog raznolikosti rezultata brojnih drugih studija, za donošenje konačnih zaključaka, potrebna su još daljnja istraživanja.

Zbog složenosti moždanog udara s njegovim tipovima i podvrstama, rezultati njihove reakcije na onečišćenje zraka razlikuju se. Neke studije pokazuju vezu između kardioemboličkog moždanog udara i zagađenog zraka, druge sa subarahnoidalnim krvarenjem, ali ne i intracerebralnog krvarenjem. Bilo je nagovještaja i da je izlaganje dušičnom dioksidu povezano s moždanim udarom uzrokovanim bolešću malih žila, dok druge studije ne opisuju tu povezanost sa rizikom od ishemijskog moždanog udara. U nekim je istraživanjima zagađeni zrak više utjecao na mlade odrasle osobe, a u nekim je bio izraženiji i kod žena. Neke studije izvijestile su očitiju vezu između zagađenja zraka i nedavnog moždanog udara u bolesnika s drugim faktorima rizika poput dijabetesa i prethodnog moždanog udara.

Studije su varirale o koncentraciji i vrstama ispitivanih onečišćujućih tvari, koje se razlikuju geografski, kao i po trajanju kratkoročnog ili dugoročnog izlaganja onečišćenom zraku a u nekim su studijama uzročne povezanosti prisutne samo tijekom toplih doba godine. U mnogim zemljama Europe i SAD-u su na snazi propisi kojima se potiče poboljšanje kvalitete sraka, što je, između ostalog, rezultiralo dužim životnim vijekom, a što ukazuje na trajnu važnost daljnjih napora istaživanju utjecaja onečišćenog zraka na ljudsko zdravlje.

KLJUČNE RIJEČI: Zagađenje zraka; Rizični faktori za moždani udar; Koncentracija zagađivača; Duljina izloženosti; 


\section{INTRODUCTION}

Airborne chemical contamination is a major environmental risk factor worldwide and contributes significantly to many diseases, including neurologic diseases.

At the XXIV World Congress of Neurology (WCN) in Dubai this year, a session on the environment and neurology explored the link between environmental contamination and neurologic disorders. Environmental pollution is considered the third greatest contributor to disability-adjusted life years (DALYs) due to stroke, as supported by observations of seasonal, diurnal, and geographic variations in stroke incidence. Strokes track very closely with and soon after increases in conjunction with levels of carbon monoxide, sulfur dioxide, nitrogen dioxide, and fine particulate matter $(\leq 2.5 \mu \mathrm{m})$.

Air pollution causes $7.6 \%$ of all deaths making it the the fifth cause of death globally and this figure is expected to increase by $50 \%$ by $2050^{1}$.

The impact of air pollution on overall health and especially on stroke has been the matter of investigation for many years. In the Global Burden of Disease Study, it has emerged as a significant contributor to global stroke burden, especially in low- and middle-income countries ${ }^{2}$.

In January 2019, the World Health Organization recognized air pollution as "the greatest environmental risk to health." ic pollutants - including airborne particulate matter (PM), ozone, sulphur dioxide, carbon monoxide, nitrogen dioxide, and nitrogen oxide - represent the greatest risk to human health ${ }^{4}$.

Crucially, air pollution differs from other modifiable risk factors for cardiovascular disease because exposure to air pollution, for the large majority of people, is unavoidable. Even though the individual risk estimates for exposure to air pollution are relatively small compared to other cardiovascular risk factors...the overall population attributable risk and the subsequent burden are significant ${ }^{4}$.

Air pollution is an expansive term consisting of a complex mixture of thousands of components from a wide range of different sources. The main pollutants currently recognised to pose the risk to health include airborne particulate matter (PM) and gaseous pollutants such as ozone $\left(\mathrm{O}_{3}\right)$, sulphur dioxide $\left(\mathrm{SO}_{2}\right)$, carbon monoxide $(\mathrm{CO})$, and nitrogen oxides including nitrogen dioxide $\left(\mathrm{NO}_{2}\right)$ and nitrogen oxide $(\mathrm{NOx})^{4}$.

Particulate matter causes endothelial dysfunction and induces thrombosis by altering reactive oxygen species, nitric oxide, insulin resistance and lipid levels, as well as transiently increasing blood coagulability and plaque rupture ${ }^{1}$.

A study review by Genc $S$ et $\mathrm{al}^{5}$ found that air pollution affects the central nervous system through a variety of cellular, molecular, and inflammatory pathways that damage brain structures or predispose those who are exposed to neurological diseases. Fine PM and nanoparticles trigger the release of soluble inflammatory mediators within the body, which then rapidly enter the circulatory system and have the potential to directly affect the vascular system.

A number of studies, published since 2002. were reviewed to assess the relation between air pollution and stroke with age, geographical location, particulate and gaseous matter type, duration of exposure, previous stroke, and comorbidities. It remains to be defined if air pollution has pathophysiological effects that preferentially predispose individuals to ischemic or hemorrhagic stroke. There is ample evidence showing an association between acute and chronic exposure to PM2.5 or gaseous pollutants with stroke. This potentially avoidable scenario and its dramatic consequences are heavily under-recognized by health professionals and the wider public. Preventive measures in people at high vascular risk are warranted ${ }^{1}$.

Even though some research has suggested a link between air pollution and ischemic stroke, drawing definitive conclusions has proven elusive and many authors still suggest further research.

Study Short-term changes in ambient particulate matter and risk of stroke: a systematic review and a meta-analysis, ${ }^{6}$ provided a comprehensive review of all observational human studies (January 1966 to January 2014) on the association between short-term changes in ambient PM levels and cerebrovascular events. They also performed meta-analyses to evaluate the evidence for an association between each PM size fraction (PM2.5, PM10, PM2.5-10) and each outcome (total cerebrovascular disease, ischemic stroke/transient ischemic attack, hemorrhagic stroke) separately for mortality and hospital admission. They used a random-effects model to estimate the summary per cent change in relative risk of the outcome per $10-\mu \mathrm{g} / \mathrm{m}^{3}$ increase in $\mathrm{PM}^{3}$.

It was found that PM2.5 and PM10 are associated with a $1.4 \%$ (95\% CI $0.9 \%$ to $1.9 \%$ ) and $0.5 \%$ (95\% CI $0.3 \%$ to $0.7 \%$ ) higher total cerebrovascular disease mortality, respectively, with evidence of inconsistent, nonsignificant associations for hospital admission for total cerebrovascular disease or ischemic or hemorrhagic stroke. Currently, limited evidence does not suggest an association between PM2.5-10 and cerebrovascular mortality or morbidity. The authors discussed the potential sources of variability in results across studies highlighted some observations, and identified gaps in the literature and made recommendations for future studies.

Shah et al. ${ }^{7}$ performed a meta-analysis of the association between air pollution, stroke admissions, and death from stroke. From 2748 articles, 238 were reviewed in-depth with 103 satisfying the inclusion criteria and 94 contributing to our meta-estimates. This provided a total of 6.2 million events across 28 countries. Admission to hospital for stroke or mortality from stroke was associated with an increase in concentrations of carbon monoxide (relative risk 1.015 per $1 \mathrm{ppm}$, 95\% confidence interval 1.004 to 1.026 ), sulphur dioxide (1.019 per $10 \mathrm{ppb}, 1.011$ to 1.027$)$, and nitrogen dioxide (1.014 per 10 ppb, 1.009 to 1.019). Increases in PM2.5 and PM10 concentration were also associated with admission and mortality (1.011 per 10 $\mu \mathrm{g} / \mathrm{m}^{3}$ (1.011 to 1.012 ) and 1.003 per $10 \mu \mathrm{g} / \mathrm{m}^{3}$ (1.002 to 1.004 ), respectively). The weakest association was seen with ozone (1.001 per $10 \mathrm{ppb}, 1.000$ to 1.002$)$. Strongest associations were observed on the day of exposure with more persistent effects observed for PM2.5. It was shown that gaseous and particulate air pollutants have a marked and close temporal association with admissions to hospital for stroke 
or mortality from stroke. Public and environmental health policies to reduce air pollution could reduce the burden of stroke.

Although a small proportion of studies originated in low- and middle-income countries, these countries showed the greatest proportion of stroke burden associated with pollution. Since both stable pollution levels and rapid changes (over a period of hours) in pollutant concentrations correlate with vascular events, it is important to consider the date of onset of symptoms (not the date of hospital admission or death) to correctly assess causal exposure to pollution (8). In Air pollution and subtypes, severity and vulnerability of ischemic stroke - A population-based case-crossover study ${ }^{9}$ authors analyzed stroke cases from the South London Stroke Register to identify patients with first-time strokes in a geographically-defined area. They used the Oxford Clinical and Trial of Org 10172 in Acute Stroke Treatment (TOAST) criteria to classify stroke subtype. To classify stroke severity, they used a clinical classification system.

Data on air pollution concentrations and exposures came from air pollution monitoring stations linked to postal codes. Researchers also evaluated lags in air pollutant effects ranging from zero to six days.

They studied the following pollutants: particulate matter less than 10 microns in diameter (PM10), $\mathrm{NO}_{2}$, ozone $\left(\mathrm{O}_{3}\right)$, carbon monoxide (CO), and sulfur dioxide $\left(\mathrm{SO}_{2}\right)$.

Overall... there was no the consistent pattern between short term exposure and increased risk of ischemic stroke subtypes or severity. The possible exception was the suggestion that $\mathrm{NO}_{2}$ (nitrogen dioxide) exposure might be associated with stroke caused by cerebrovascular small vessel disease

Between 1995-2006, 2590 cases of ischemic stroke occurred (mean age 71.7 years, $49.7 \%$ female, $75.6 \%$ white), $62.5 \%$ had pre-existing hypertension, $59.9 \%$ had a past transient ischemic attack, nearly one-fifth had preexisting coronary heart disease, atrial fibrillation, or diabetes. No clear link between ischemic stroke and pollutants, in relation to pre-existing risk factors, including lifestyle, pre-existing medical conditions, and sociodemographic factors.

Some positive links between several pollutants at various lag times, but no overall consistent pattern between pollutants and risk of ischemic stroke subtypes or severity with possible exception - the risk of stroke from small vessel disease increased with increasing exposure to NO2: 3-day lag: OR 1.21 (1.00-1.46), 5-day lag: 1.21 (1.01-1.45), 6-day lag: $1.26(1.05-1.52)$, average over 6 days: OR $1.51(1.12-2.02)$.

In the study Fine Particulate Air Pollution (PM2.5) and the Risk of Acute Ischemic Stroke ${ }^{10}$, the authors analyzed data from 9202 patients hospitalized with acute ischemic stroke, having a documented date and time of stroke onset, and residing within $50 \mathrm{~km}$ of a PM2.5 monitor in 8 cities in Ontario, Canada. Results do not support the hypothesis that short-term increases in PM2.5 levels are associated with ischemic stroke risk overall. However, specific patient subgroups may be at increased risk of particulate-related ischemic strokes. In conclusion, data from this perspective, the multicenter study suggest that short-term elevations of ambient fine particulate matter are associated with increased risk of ischemic stroke onset among patients with diabetes mellitus and those hospitalized with noncardioembolic strokes. The authors suggest that additional research is required to confirm these findings in larger cohorts of patients with detailed information.

To assess the relationship between short-term exposure to outdoor ambient air pollutants - fine particulate matter (PM2.5) and black carbon (BC) and ischemic stroke (IS) and its different subtypes, and the potential modifying effect of neighbourhood greenspace and noise, the authors ${ }^{11}$ analyzed 2742 cases with known onset date and time, living in the study area, from BASICMAR 2005-2014. stroke registry. Overall, no association was found between PM2.5 and $\mathrm{BC}$ (black carbon) exposure and acute IS risk. By stroke subtype, a large-artery atherosclerotic stroke could be triggered by daily increases in BC, a diesel fuel-related pollutant in the study area.

Data from Dijon Stroke Register between March 1994 and December 2004. ${ }^{12}$ with 2078 strokes analyzed pollutant concentrations $\left(\mathrm{SO}_{2}, \mathrm{CO}, \mathrm{NO}_{2}, \mathrm{O}_{3}\right.$ and PM10), which were measured hourly. The only positive finding was an association between $\mathrm{O}_{3}$ and ischemic stroke at a 1-day lag - only significant in men, over 40 years of age and only for large vessel disease $(\mathrm{p}=0,02)$ and for TIA $(\mathrm{p}=0,01)$. There were no significant associations for haemorrhagic stroke. They found an increase in association in men with several cardiovascular risk factors (smoker, dyslipidemia and hypertension).

All members of the largest health maintenance organization in Israel, who were admitted to a local hospital with stroke between 2005 and 2012.13 were analyzed. A number of 4837 stroke cases were identified $89.4 \%$ being ischemic stroke). The interquartile range of $\mathrm{PM}<10$ and $<2.5 \mu \mathrm{m}$ was 36.3 to 54.7 and 16.7 to 23.3 $\mu \mathrm{g} / \mathrm{m} 3$, respectively. Higher risk for ischemic stroke associated with PM among young adults was observed. The authors pointed out that this finding can be explained by the inflammatory mechanism, linking air pollution and stroke.

To assess who is the most vulnerable to stroke, during the short-term exposure to ambient air pollution

the authors analyzed this association during the year ${ }^{14}$. They observed positive associations between ischemic stroke and air pollution during the 'warm' season (April through September). There were no statistically significant associations with any of the other pollutants after adjusting for $\mathrm{NO}_{2}$ concentrations. Associations with ischemic stroke were stronger for those with a history of stroke $(\mathrm{OR}=2.31$; 95\% CI: 1.39, 3.83), heart disease (OR=1.99; 95\% CI: $1.20,3.28)$, and taking medication for diabetes $(\mathrm{OR}=2.03$; $95 \% \mathrm{CI}$ : $1.14,3.59)$. The temperature was inversely associated with ischemic stroke during the 'warm' season, but no associations were evident with the other stroke subtypes. Air pollution was not associated with hemorrhagic stroke or transient ischemic attacks.

The findings suggest that specific patient characteristics modify associations between air pollution and ischemic stroke. Levels of particulate and gaseous air pollution were measured from 1998 to 2004 at central outdoor monitoring sites in Helsinki.

Associations between daily levels of air pollutants and deaths caused 
by stroke among persons aged 65 years or older were evaluated in warm and cold seasons using Poisson regression. Results suggest that especially PM2.5, but also ultrafine particles and carbon monoxide, are associated with increased risk of fatal stroke, but only during the warm season. The effect of the season might be attributable to seasonal differences in exposure or air pollution mixture ${ }^{15}$.

In the cohort study, analyzing stroke and long.term exposure to outdoor air pollution from nitrogen dioxide, the authors found the new evidence that long-term exposure to traffic-related air pollution in adult life may be a risk factor for ischemic stroke but not hemorrhagic stroke. Fatal ischemic strokes, likely denoting admissions for more severe strokes, were most strongly associated with $\mathrm{NO}_{2}{ }^{16}$.

Data obtained from the Takashima Stroke and AMI Registry, which covers a population of approximately 55,000 in Takashima County in central Japan were analyzed ${ }^{17}$. There were 2,038 first-ever strokes (1,083 men, 955 women) and 429 first-ever AMI cases (281 men, 148 women) during 1988-2004. The mean pollutant levels were as follows: SPM $26.9 \mu \mathrm{g} / \mathrm{m} 3 ; \mathrm{SO}_{2} 3.9 \mathrm{ppb} ; \mathrm{NO}_{2} 16.0 \mathrm{ppb}$, and $\mathrm{Ox}$ $28.4 \mathrm{ppb}$. In single-pollutant and two-pollutant models, $\mathrm{SO}_{2}$ was associated with the risk of a cerebral haemorrhage. Other stroke subtypes and AMI were not associated with air pollutant levels. Association between hemorrhagic stroke occurrence and meteorological factors and pollutants were analyzed ${ }^{18}$, and findings showed the relationship between hemorrhagic stroke and meteorological parameters and pollutants under similar weather and environmental conditions in a small area. Among meteorological and pollutant variables, only higher particulate matter concentrations correlated independently with intracerebral haemorrhage occurrence, while only ozone was independently associated with subarachnoid haemorrhage occurrence. These findings suggest the possibility that there are pathogenic associations between hemorrhagic stroke and meteorological factors and pollutants.

In another study, the same authors ${ }^{19}$ studied monthly variations in aneurysmal subarachnoid haemorrhage incidence and mortality and eventual correlation with weather and pollution. There was a trend toward lower SAH occurrence in the summer and higher SAH occurrence in January and during the change of seasons. These trends were significantly associated with the mean monthly temperature and diurnal temperature range. However, no correlation was observed between SAH mortality and meteorological/air pollution parameters. These findings suggest that meteorological factors may play an important role in monthly variations in the occurrence of aneurysmal $\mathrm{SAH}$, although aneurysm rupture itself is likely to be multifactorial. A recent study ${ }^{20}$ analyzed long - term exposure to air pollution and survival after ischemic stroke in China National Stroke Registry Cohort. This first national hospital-based prospective registry cohort of stroke in China included 12291 ischemic stroke patients who visited hospitals from 2007 to 2008. All patients were followed for 1-year post-stroke. Deaths during the follow-up period were recorded. Participants' 3-year pre-stroke exposures to ambient PM1, PM2.5, PM10 (particulate matter with aerodynamic diameters $\leq 1, \leq 2.5$, and $\leq 10 \mu \mathrm{m}$, respectively) and $\mathrm{NO}_{2}$ ( nitrogen dioxide) were estimated by machine learning algorithms with satellite remote sensing, land use information, and meteorological data. Cox proportional hazards models were used to examine the association between air pollution and survival after ischemic stroke. In total, 1649 deaths were identified during the 1-year follow-up period. After controlling for potential confounders, significant associations were observed between exposure to PM1 and PM2.5 and incident fatal ischemic stroke, showing that pre-stroke exposure to PM1 and PM2.5 was associated with increased incident fatal ischemic stroke in the year following an ischemic stroke in China. Improved air quality may be beneficial for people to recover from stroke.

In the cohort of post-menopausal women across the US, the authors found little evidence to support the hypothesis that transient elevations in ambient PM2.5, PM10, $\mathrm{SO}_{2}$, or $\mathrm{O}_{3}$ were associated with higher relative risk of total stroke, ischemic stroke, or hemorrhagic stroke. Daily levels of $\mathrm{NO}_{2}$ and $\mathrm{NOx}$ were likewise not associated with the relative risk of total stroke or ischemic stroke, although we did find that transient changes in $\mathrm{NO}_{2}$ and $\mathrm{NOx}$ were associated with higher risk of hemorrhagic stroke with the strongest association observed with a 3-day moving average prior to stroke hospitalization. Additional studies are still needed to conclusively establish or refute the hypothesis that short-term changes in ambient air pollution levels are associated with a higher risk of stroke ${ }^{21}$.

Recent review describes clinical and epidemiological studies examining the adverse effects of urban air pollution on the central nervous system (CNS). Air pollution and particulate matter (PM) are associated with neuroinflammation and reactive oxygen species (ROS) and these processes affect multiple CNS pathways. Exposures to air pollution impact cognitive function, stroke risk, and carotid artery disease. Pediatric and elderly populations are highly vulnerable due to CNS development and ageing processes. Compiling and contextualizing current evidence should provoke thought and future investigations focused on improving health outcomes ${ }^{22}$.

The acute effect of air pollutants on ischaemic stroke (IS) and IS-related death in five urban districts in Changzhou, China was investigated between 9 January 2015 and 31 December 2016. A total of 32840 IS cases and 4028 IS deaths were enrolled. The results suggested that short-term exposure to ambient $\mathrm{NO}_{2}$ was associated with increased IS risk. In addition, $\mathrm{SO}_{2}$ was associated with increased IS counts and deaths. These findings may have significant public health implications for the prevention of IS and IS-related deaths. The authors recommended further studies to validate their research ${ }^{23}$. In the study related to short-term exposure to ambient fine particulate matter (PM2,5 and PM10) and the risk of heart rhythm abnormalities and stroke, in case of stroke the authors found a stronger correlation between the number of hospitalizations and death cases and exposure to fine dust for ischaemic stroke than for haemorrhagic stroke. In addition, a the significantly more harmful impact of the exposure to ultra particles (particles of aerodynamic diameter below 2,5 $\mu \mathrm{m}$ ) has been confirmed. Among important mechanisms respon- 
sible for the observed health impact of particulate matter there are induction and intensification of inflammation, increased oxidative stress increased autonomic nervous system activity, vasoconstriction, rheological changes and endothelial dysfunction. Among people of higher susceptibility to fine dust negative health impact are: elderly (over 65 years old), obese people, patients with respiratory and cardiovascular diseases, patients with diabetes and those with coagulation disorders ${ }^{24}$.

In another study of short-term exposures to ambient air pollution and risk of recurrent ischemic stroke in order to investigate the association between short-term changes in ambient pollution (particulate matter $<2.5 \mu \mathrm{m}$ in aerodynamic diameter (PM2.5) and ozone $\left(\mathrm{O}_{3}\right)$ ) and the risk of recurrent ischemic stroke among individuals living in a bi-ethnic community, there were no evidence of associations between previous-day air pollution levels and recurrent ischemic stroke. The authors pointed out that research on the influence of air pollutants on risk of stroke recurrence is still in its infancy, and more research is necessary for studies that are adequately powered to understand the relation ${ }^{25}$.

In the Japanese study authors analyzed data for 6885 ischemic stroke patients from a multicenter hospital-based stroke registry in Japan who were previously independent and hospitalized within 24 hours of stroke onset. Time of symptom onset was confirmed, and the association between PM (suspended PM and PM2.5) and the occurrence of ischemic stroke was analyzed by time stratified case-crossover analysis.

Ambient PM2.5 and suspended PM at lag days 0 to 1 were associated with subsequent the occurrence of ischemic stroke (ambient temperature-adjusted odds ratio [95\% confidence interval] per $10 \mu \mathrm{g} /$ $\mathrm{m}^{3}$ : suspended PM, 1.02 [1.00-1.05]; PM2.5, 1.03 [1.00-1.06]). In contrast, ambient suspended PM and PM2.5 at lag days 2 to 3 or 4 to 6 showed no significant association with stroke occurrence. The association between PM2.5 at lag days 0 to 1 and ischemic stroke was maintained after adjusting for other air pollutants (nitrogen dioxide, photochemical oxidants or sulfur dioxide) or influenza epidemics and was evident in the cold season. These findings suggest that short-term exposure to PM2.5 within 1 day before onset is associated with the subsequent occurrence of ischemic stroke ${ }^{26}$.

In another study ${ }^{27}$ authors reviewed the medical records of 1705 Boston area patients hospitalized with neurologist confirmed ischemic stroke and abstracted data on the timeof symptom onset and clinical characteristics. The PM2.5 concentrations were measured at a central monitoring station. They used the time-stratified case-crossover study design to assess the association between the risk of ischemic stroke onset and PM2.5 levels in the hours and days preceding each event. They examined whether the association with PM2.5 levels differed by presumed ischemic stroke pathophysiologic mechanism and patient characteristics.

The increase in risk was greatest within 12 to 14 hours of exposure to PM2.5 and was most strongly associated with markers of traffic-related pollution suggesting that exposure to PM2.5 levels considered generally safe by the US EPA increase the risk of ischemic stroke onset within hours of exposure.

As evidence from epidemiological studies has demonstrated that outdoor air pollution is now a well-known major problem of public health, mainly in low and middle income countries, but contrasting with myocardial infarction, there are few data on the association of air pollution and stroke, the authors proposed a narrative literature review of the effects and the underlying biological mechanisms of short- and long-term exposure to air pollutants on stroke risk and mortality, using data from Dijon Stroke Registry with the following key-words: stroke, cerebrovascular events, ischemic and haemorrhage stroke, transient ischaemic attack, mortality, air pollution and air pollutants. Twenty-one papers were selected. Air pollution, of which whose small particulate matter are the most toxic, contributes to about one-third of the global burden of stroke. They could identify vulnerable patients with classical neuro-vascular risk factors or a prior history of stroke or transient ischemic attack or persons living in low-income countries. Biological mechanisms of this new morbid association are discussed. Air pollution should be recognized as a silent killer inducing stroke whose mortality rates remain elevated by its role as a new modifiable neurovascular risk factor, needing public health policies ${ }^{28}$.

As some subpopulations may be particularly vulnerable to PM pollution, in this review focus was on one subgroup, long-term stroke survivors, and the emerging evidence suggesting that survivors of a stroke may be at a higher risk from the deleterious effects of PM pollution. While the mechanisms for mortality are still under debate, long-term stroke survivors may be vulnerable to similar mechanisms that underlie the well-established association between PM pollution and cardiovascular disease. The fact that long-term stroke survivors of ischemic, but not hemorrhagic, strokes appear to be more vulnerable to the risk of death from higher PM pollution may also bolster the connection to ischemic heart disease. Survivors of an ischemic stroke may be more vulnerable to dying from higher concentrations of PM pollution than the general population. The clinical implications of this association suggest that reduced exposure to PM pollution may result in fewer deaths amongst stroke survivors ${ }^{29}$.

The World Health Organization (WHO) has estimated that 90\% of the world's population breathes air that exceeds WHO contamination limits. The Global Burden of Diseases study 2015 estimated that 898,100 cerebrovascular disease deaths and 19.2 million DALYs were attributable to ambient particulate matter air pollution ${ }^{30}$. Air pollution accounts for nearly $30 \%$ of global stroke burden, with the greatest effects in low- and middle-income countries. In these countries, much of the pollution is within households as a result of incomplete combustion of fuels for cooking and heating. Long-term exposure to airborne contaminants results in accelerated carotid atherosclerosis, damage to vascular endothelium, increased sympathetic nervous system activity, vasoconstriction, increased blood pressure, and thrombosis. Acute exposures affect cerebrovascular hemodynamics and vascular resistance, with reduced blood 
flow and atrial arrhythmia. Not only are these exposures important risk factors for neurodegenerative diseases, but they also play a role in neurodevelopmental disorders.

Even solid particles in the environment can affect the nervous system. It has been documented that solid plastic nanoparticles work their way up the food chain; they are ingested by algae, which are eaten by daphnia, then spread to fish, disrupting the function of ecosystems all along the way. Eventually these particles end up at the top of the food chain, including humans. They are small enough to cross the blood-brain barrier.

\section{CONCLUDING REMARKS:}

Due to huge diversity of results of numerous studies, for drawing definitive conclusions, further research is still needed.

Studies have varied by the concentration and types of pollutants studied, which vary geographically, as well as by duration to AP exposure, being acute, short or long, and in some studies being present only during the warm season.
Due to the complexity of stroke with its types and subtypes, the results of their reaction to air pollution differ. Who is more susceptible to getting an ischemic stroke, or eventually haemorrhagic? Is the combination with other risk factors important, and especially with which of them? Also, there is a possible publication bias as negative studies are less likely to be published.

Nevertheless, regulations have improved air quality in many countries in Europe and the United States, resulting in greater life expectancy, which highlights the continued importance of further efforts in that direction.

\section{AUTHOR CONTRIBUTIONS:}

All authors listed have made a substantial, direct and intellectual contribution to the work, and approved it for publication.

\section{LITERATURE:}

1. Estol CJ. Is breathing our polluted air a risk factor for stroke? International Journal of Stroke. 0(0) 1-11. Article reuse guidelines: sagepub.com/journals-permissions DOI: 10.1177/1747493019832999 journals.sagepub.com/home/wso

2. Feigin VL, Roth GA, Naghavi M, et al. Global burden of stroke and risk factors in 188 countries, during 1990-2013: a systematic analysis for the Global Burden of Disease Study 2013. Lancet Neurol. 2016;15:913-24.

3. World Health Organization. Ten threats to global health in 2019. https://www.who.int/emergencies/ten-threats-to-global-healthin-2019.

4. Lee KK, Miller MR, Shah ASV. Air pollution and stroke. Stroke. 2018;20(1):2-11.

5.Genc S, Zadeoglulari Z, Fuss SH, et al. The adverse effects of air pollution on the nervous system. J Toxicol. 201. Article ID:782462. 6. Wang Y, Eliot MN, Wellenius GA. Short-term changes in ambient particulate matter and risk of stroke: a systematic review and meta-analysis. J Am Heart Assoc. 2014;3(4). pii: e000983. doi: 10.1161/ JAHA.114.000983.

7. Shah AS, Lee KK, McAllister DA, et al. Short term exposure to air pollution and stroke: systematic review and meta-analysis. BMJ. 2015;350:h1295.

8. Rasche M, Walther M, Schiffner R, et al. Rapid increases in nitrogen oxides are associated with acute myocardial infarction: a case-crossover study. Eur J Prev Cardiol. 2018;25:1707-1716. 9. Maheswaran R, Pearson T, Beevers SD, et al. Air pollution and subtypes, severity and vulnerability to ischemic stroke - a population based case-crossover study. PloS One 2016;11:e0158556.

10. O’Donnell MJ, Fang J, Mittleman MA, et al. Fine particulate air pollution (PM2.5) and the risk of acute ischemic stroke. Epidemiology. 2011;22:422-431.

11. Vivanco-Hidalgo RM, Avellaneda-Gómez C, Dadvand P, et al. Association of residential air pollution, noise, and greenspace with initial ischemic stroke severity. Environ Res. 2019;179(Pt A):108725. doi: 10.1016/j.envres.2019.108725. [Epub ahead of print]
12. Henrotin JB, Besancenot JP, Bejot Y, et al. Short-term effects of ozone air pollution on ischaemic stroke occurrence: a case-crossover analysis from a 10-year population-based study in Dijon, France. Occup Environ Med 2007;64: 439-445.

13. Sade MY, Novack V, Ifergane G, et al. Air pollution and ischemic stroke among young adults. Stroke. 2015;46:3348-3353.

14. Villeneuve PJ, Johnson JYM, Pasichnyk D, et al. Shortterm effects of ambient air pollution on stroke: who is most vulnerable? Sci Total Environ. 2012;430:193-201.

15. Kettunen J, Lanki T, Tiittanen P, et al. Associations of fine and ultrafine particulate air pollution with stroke mortality in an area of low air pollution levels. Stroke. 2007;38:918-922.

16. Andersen ZJ, Kristiansen LC, Andersen KK, et al. Stroke and Long-Term Exposure to Outdoor Air Pollution From Nitrogen Dioxide. A Cohort Study. Stroke. 2012;43(2):320-5. doi: 10.1161/ STROKEAHA.111.629246.

17. Turin TC, Kita Y, Rumana N, et al. Short-Term Exposure to Air Pollution and Incidence of Stroke and Acute Myocardial Infarction in a Japanese Population. Neuroepidemiology 2012;38:84-92. https:// doi.org/10.1159/000335654.

18. Han MH, Yi HJ, Ko Y, et al. Association between hemorrhagic stroke occurrence and meteorological factors and pollutants. BMC Neurol. 2016;16:59. doi: 10.1186/s12883-016-0579-2.

19. Han MH, Kim J, Choi KS, et al. Monthly variations in aneurysmal subarachnoid hemorrhage incidence and mortality: Correlation with weather and pollution. . PLoS ONE 12(10): e0186973. https:// doi. org/10.1371/journal.pone.0186973.

20. Chen G, Wang A, Li S, et al. Long-Term Exposure to Air Pollution and Survival After Ischemic Stroke. The China National Stroke Registry Cohort. Stroke. 2019;50:563-570. DOI: 10.1161/STROKEAHA.118.023264.

21. Sun S, Stewart JD, Eliot MN, et al. Short-term exposure to air pollution and incidence of stroke in the Women's Health Initiative. Environment International. 2019;132, ID 105065. https://doi. org/10.1016/j.envint.2019.105065.

22. Babadjouni RM, Hodis DM, Radwanski R, et al. Clinical effects of 
air pollution on the central nervous system; a review. J Clin Neurosci. 2017;43:16-24.

23. Dong H, Yu Y, Yao S, et al. Acute effects of air pollution on ischaemic stroke onset and deaths: a time-series study in Changzhou, China. BMJ Open. 2018;8:e020425. doi:10.1136/bmjopen-2017-020425.

24. Kowalska M, Kocot K. Short-term exposure to ambient fine particulate matter (PM2,5 and PM10) and the risk of heart rhythm abnormalities and stroke. Postepy Hig Med Dosw (Online). 2016 Sep $28 ; 70(0): 1017-1025$.

25. Wing JJ, Adar S, Sanches B, et al. Short-Term Exposures to Ambient Air Pollution and Risk of Recurrent Ischemic Stroke. Environ Res. 2017;152:304-307.

26. Matuso R, Michikawa T, Ueda K, et al. Short-Term Exposure to Fine Particulate Matter and Risk of Ischemic Stroke. Stroke. 2016;47:3032-3034. doi:10.1161/STROKEAHA.116.015303. 27. Wellenius GA, Burger RM, Coull, BA; Schwartz, J; Suh, HH; Koutrakis, P; Schlaug, G; Gold, DR; Murray A. Ambient Air Pollution and the Risk of Acute Ischemic Stroke,

Arch Intern Med. 2012;172(3):229-234

28. Graber M, Mohr S, Baptiste L, Duloquin G, Blanc-Labarre C, Mariet AS, Giroud M, Béjot Y. Air pollution and stroke. A new mod- ifiable risk factor is in the air. Rev Neurol (Paris). 2019 May 29. pii: S0035-3787(18)30976-7. doi: 10.1016/j.neurol.2019.03.003. 29. Desikan A. Outdoor air pollution as a possible modifiable risk factor to reduce mortality in post-stroke population. Neural Regen Res. 2017 Mar;12(3):351-353. doi: 10.4103/1673-5374.202917.

30. Cohen AJ et al.Estimates and 25-year trends of the Global Burden of Disease attributable to ambient air pollution:ananalysis of data from the Global burden of disease study 2015. The Lancet. 2017,389:1907-1918 doi:10.1016/S0140-6736(17)30505-6

31. Béjot, Y., Reis, J., Giroud, M., \& Feigin, V. (2018). A review of epidemiological research on stroke and dementia and exposure to air pollution. International Journal of Stroke, 13(7), 687-695. https:// doi.org/10.1177/1747493018772800

32. Zhang, R., Liu, G., Jiang, Y., Li, G., Pan, Y., Wang, Y., ... Wang, Y. (2018). Acute Effects of Particulate Air Pollution on Ischemic Stroke and Hemorrhagic Stroke Mortality. Frontiers in Neurology, 9. https://doi.org/10.3389/fneur.2018.00827

33. Tian, Y., Liu, H., Zhao, Z., Xiang, X., Li, M., Juan, J., ... Gao, P. (2018). Association between ambient air pollution and daily hospital admissions for ischemic stroke: A nationwide time-series analysis. PLOS Medicine, 15(10), e1002668. https://doi.org/10.1371/journal. pmed. 1002668 